\title{
Modeling the formation of free volume at grain boundaries and triple junctions during nickel crystallization
}

\author{
G. M. Poletaev ${ }^{\dagger, 1}$, D. V. Novoselova ${ }^{2}$, R. Y. Rakitin ${ }^{3}$, A. S. Semenov ${ }^{4}$ \\ †gmpoletaev@mail.ru \\ ${ }^{1}$ Altai State Technical University n. a. I. I. Polzunov, 46 Lenina Av., Barnaul, 656038, Russia \\ ${ }^{2}$ Kuzbass Institute of the Federal Penitentiary Service of Russia, 49 Oktyabrsky Av., Novokuznetsk, 654066, Russia \\ ${ }^{3}$ Altai State University, 61 Lenin Av., Barnaul, 656049, Russia \\ ${ }^{4}$ Polytechnic Institute of North-Eastern Federal University, 5 Tikhonova St., Mirny, 678170, Russia
}

The molecular dynamics method was used to study the formation of free volume at grain boundaries and triple junctions during crystallization using nickel as an example. To simulate the crystallization process, crystalline nuclei were used - small ideal crystals with a fixed lattice. The orientation of the crystal lattice in the nuclei was set randomly, but so that tilt boundaries with the misorientation axis $<100>$ or $<111>$ were formed in the result of crystallization. It is shown that the free volume during crystallization is predominantly concentrated at grain boundaries and triple junctions, and more so in the latter ones, i. e. where the last solidification of the structure occurs and crystallization fronts are encountered. The reduced density of the structure at triple junctions compared with grain boundaries is explained by the fact that when three crystallization fronts meet, the volume is fixed, where the liquid phase having a density lower than that of the crystal solidifies. The velocity of crystallization front motion is several tens of times lower than the speed of sound in a metal, therefore, defects, as a rule, formed only in the last turn - when the fronts meet, i.e. at grain boundaries and triple junctions. Disclinations at triple junctions were not observed in this work. During crystallization, relatively small subgrains with an orientation different from the neighboring grains, and usually in a stretched state, sometimes appeared in the region of triple junctions. But they "healed" relatively quickly, being absorbed by neighboring growing grains.

Keywords: molecular dynamics, triple junction, grain boundary, free volume, crystallization.

УДК: 538.911

\section{Моделирование формирования свободного объема в границах зерен и тройных стыках при кристаллизации никеля}

\author{
Полетаев Г. М. ${ }^{\dagger, 1}$, Новоселова Д. В. ${ }^{2}$, Ракитин Р. Ю. ${ }^{3}$, Семенов А. С. ${ }^{4}$ \\ ${ }^{1}$ Алтайский государственный технический университет им. И. И. Ползунова, \\ пр. Ленина, 46, Барнаул, 656038, Россия \\ ${ }^{2}$ Кузбасский институт ФСИН России, пр. Октябрьский, 49, Новокузнецк, 654066, Россия \\ ${ }^{3}$ Алтайский государственный университет, пр. Ленина, 61, Барнаул, 656049, Россия \\ ${ }^{4}$ Политехнический институт Северо-Восточного федерального университета им. М.К. Аммосова, \\ ул. Тихонова 5, Мирный, 678170, Россия
}

\begin{abstract}
Методом молекулярной динамики проведено исследование формирования свободного объема в границах зерен и тройных стыках при кристаллизации на примере никеля. Для имитации процесса кристаллизации использовались кристаллические зародыши - небольшие идеальные кристаллы с фиксированной решеткой. Ориентация кристаллической решетки в зародышах задавалась случайной, но такой, чтобы в результате кристаллизации получались границы наклона с осью разориентации $<100>$ или $<111>$. Показано, что свободный объем при кристаллизации преимущественно концентрируется в границах зерен и тройных стыках, причем в большей степени в последних, т. е. там, где в последнюю очередь происходит затвердевание структуры и встречаются фронты кристаллизации. Пониженная плотность структуры в тройных стыках по сравнению с границами зерен объясняется тем, что при встрече трех фронтов кристаллизации происходит фиксация объема, в котором затвердевает жидкая фаза, имеющая плотность ниже плотности кристалла. Скорость движения фронта кристаллизации в несколько
\end{abstract}


десятков раз меньше скорости звука в металле, поэтому дефекты, как правило, формировались только в последнюю очередь - при встрече фронтов, т. е. в границах зерен и тройных стыках. Дисклинации в тройных стыках в настоящей работе не наблюдались. В процессе кристаллизации в области тройных стыков иногда возникали сравнительно небольшие субзерна с отличной от соседних зерен ориентацией и находящиеся, как правило, в состоянии растяжения, но они сравнительно быстро «залечивались», поглощаясь соседними растущими зернами.

Ключевые слова: молекулярная динамика, тройной стык, граница зерен, свободный объем, кристаллизация.

\section{Introduction}

The triple junction of grain boundaries is a linear defect along which three grain boundaries are conjugated. The systems of grain boundaries and their triple junctions in metals obtained as a result of crystallization from a melt and during plastic deformation differ very much. In the latter case, the proportion of nonequilibrium boundaries and excess defects is high both at the boundaries and at the triple junctions [1-3]. But in both cases, the triple junctions differ in properties from the grain boundaries forming them. According to experimental data, diffusion in the region of the triple junction proceeds much more intensively than along the boundaries themselves $[4-8]$. The triple junction is often characterized by a relatively "loose" structure (even with inclusions of the amorphous phase [9]), that is, with a higher free volume content compared to the grain boundaries forming this junction $[8,10,11]$. This paper is devoted to the triple junctions obtained as a result of crystallization of a metal.

Earlier, in [12], we showed that the most probable reason for the formation of excess free volume at the triple junctions obtained during crystallization is the "locking" of the density of the liquid phase at the meeting of three crystallization fronts, which causes the concentration of excess free volume in the triple junction after solidification. The free volume at the triple junctions plays an important role not only in diffusion $[6,8,13]$, but also in the processes of their migration [14], and the mechanisms of deformation with their participation [15].

Fig. 1 schematically depicts the process of "locking" the free volume at triple junctions during crystallization. The speed of motion of the crystallization front is an order of magnitude lower than the speed of sound. Therefore, defects, as a rule, are formed during crystallization of pure metals in the regions where crystalline phases with different orientations are conjugated, i. e. at grain boundaries and triple junctions, and especially at the triple junctions that crystallize last. When three crystallization fronts meet (Fig. 1), the liquid phase remains at the triple junction, which has not yet crystallized (marked with the number 3). Its density is lower than the density of the crystalline phase. This lack of atoms for the formation of an "ideal" triple junction leads to the appearance of an excess free volume, which is concentrated during crystallization mainly at triple junctions.

In [12], to test this hypothesis, a computer simulation of nickel crystallization from several randomly oriented crystallization nuclei was carried out. The simulation results confirmed that the free volume can indeed be locked at triple junctions in this way. In addition, it was found in [12] that, in some cases the formation of relatively small subgrains with different orientations from the joined grains and in the stretched state is possible during crystallization in the triple junction region. However, the model used by us in [12], from our point of view, had drawbacks. Firstly, the size of the computational cell was not large enough - only 30 thousand atoms. In this case, obviously, the resulting grains were relatively small. Secondly, modeling of nickel crystallization was carried out at a relatively low temperature of the thermostat $-800 \mathrm{~K}$. In this paper, we have tried to correct these shortcomings. The use of OpenCL technology in our own program MDR allowed us to increase the size of the computational cells by an order of magnitude.

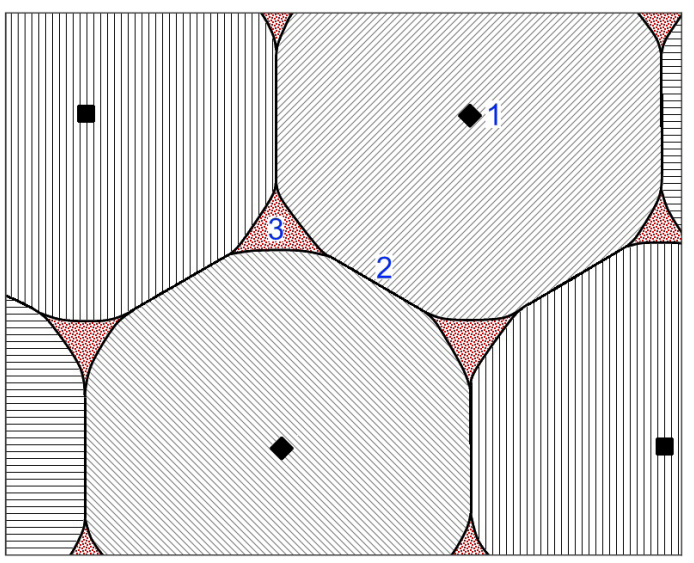

Fig. 1. (Color online) A schematic representation of the structure of a polycrystal during crystallization at the moment of meeting the crystallization fronts and the formation of pockets of the liquid phase having density smaller than that of the crystalline phase: 1 - crystallization center, $2-$ crystallization front, 3 - liquid phase in the triple junction.

\section{Description of the model}

Modeling was carried out using the molecular dynamics method. The calculation cell of nickel was in the form of a plate containing 12 specially introduced crystalline seeds (nuclei) - small cylindrical crystalline regions with a fixed atomic structure (in Fig. 2 they are highlighted in dark gray and marked with the number 1). Crystalline nuclei were used because of the complexity of modeling crystallization in the molecular dynamics model from the liquid state at typical cooling rates for this method. The nuclei were located at equal distances from each other (Fig. 2). The orientation of the crystal lattice in the nuclei was set randomly, but so that, as a result of crystallization, tilt boundaries with a misorientation axis $<100>$ or $<111>$ are obtained.

The calculated cells contained about 240 thousand atoms. The thickness of the calculation cells along the $\mathrm{Z}$ axis was approximately $25 \AA$. Height and width are 360 and $300 \AA$, 
respectively. The boundary conditions along the $\mathrm{X}$ and $\mathrm{Z}$ axes (Fig. 2) were specified periodically. Along the $\mathrm{Y}$ axis they were free, so that the computational cell could change the volume during crystallization and temperature changes.

The interactions of nickel atoms with each other were described by the Cleary-Rosato many-body tightbinding potential [16]. This potential has proven well itself in a number of calculations of the structural and energy characteristics of metals performed by the molecular dynamics method [17-19]. The time integration step in the molecular dynamics method was $2 \mathrm{fs}$. The temperature in the model was set through the initial atomic velocities according to the Maxwell-Boltzmann distribution. At the first stage of preparation of the computational cell, the positions of the atoms corresponded to the crystal structure.

Crystallization in the molecular dynamics model was carried out as follows. At first, the computational cell melted by holding at a temperature of $3000 \mathrm{~K}$ (the crystal structure in the nuclei remained fixed at the same time). After that, the temperature of the thermostat was lowered by $1500 \mathrm{~K}$ and crystallization was simulated. When setting this or that temperature, all interatomic distances in the calculation cell changed in accordance with the coefficient of thermal expansion, which was preliminary found specifically for the potential used.

\section{Results and discussion}

Fig. 2 shows an example of a computational cell during crystallization. In the figure, growing crystalline grains are clearly visible. The growth of crystals, regardless of their orientation, occurred at approximately the same rate (according to [20], this rate is several tens of times lower than the speed of sound in a metal). In this regard, the size of the resulting grains, as can be seen in Fig. 3, is about the same.

Fig. 3 shows the final structures of the calculated cells after modeling crystallization with tilt boundaries $<111>$

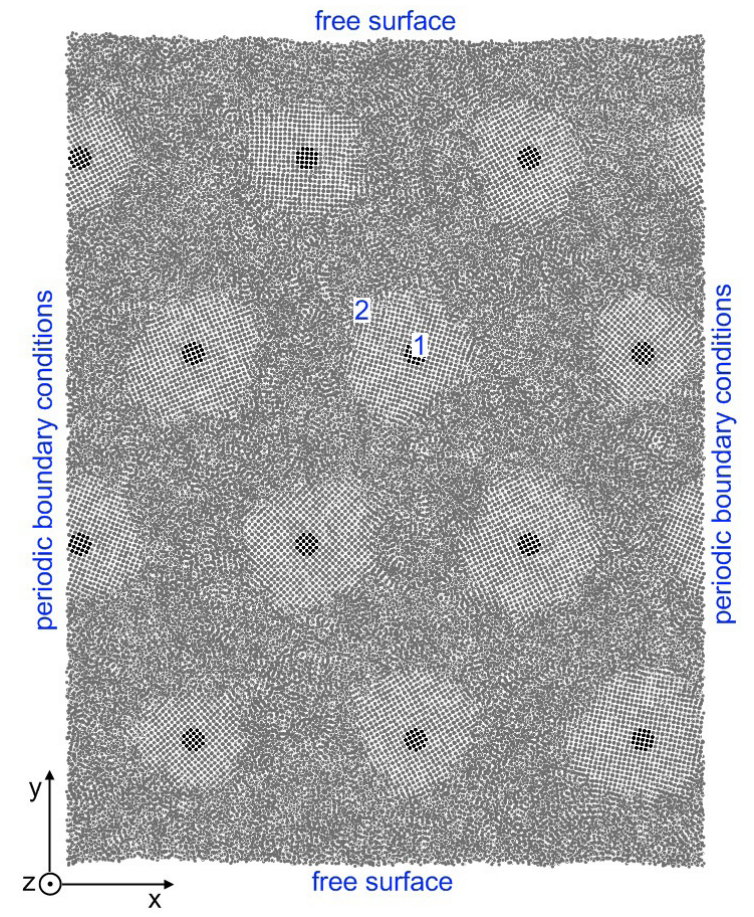

Fig. 2. Example of the computational cell in the process of crystallization modeling: 1 - crystallization nucleus, $2-$ crystallization front.

(Fig. 3a) and $<100>$ (Fig. 3b). To obtain a clearer structure, the calculated cells after the main computer experiment were cooled to a temperature close to $0 \mathrm{~K}$. To study the structures obtained, a visualizer of the average distance to the nearest atoms was used. This gives an idea of the presence of local tension and indirectly of the distribution of free volume. For each atom, the average distance to the nearest atoms was calculated. If the average distance was slightly different from the distance corresponding to the ideal crystal, the atom was not highlighted in color. Otherwise, the atom was painted over in one or another shade from light gray to dark burgundy.

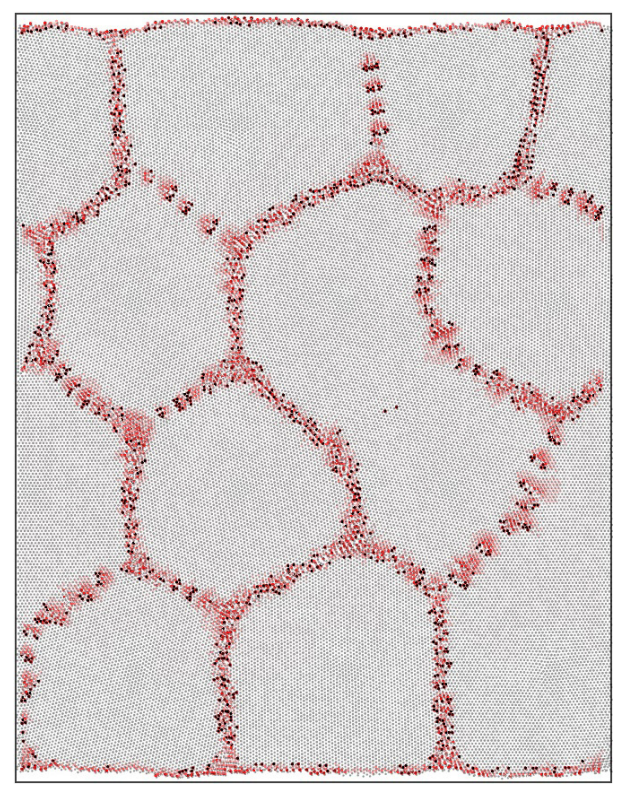

a

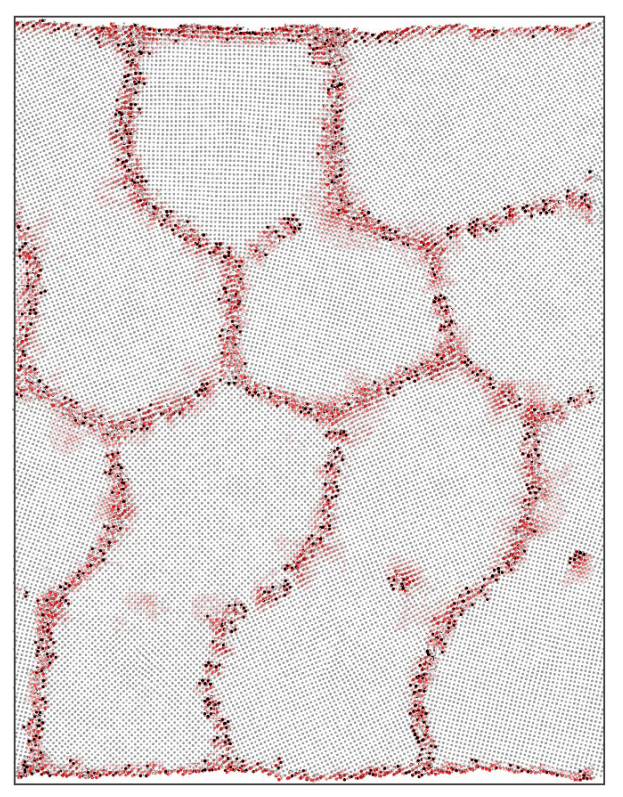

$\mathrm{b}$

Fig. 3. Distribution of free volume in the calculation cells after crystallization and subsequent cooling: with $<111>$ tilt boundaries (a), with $<100>$ tilt boundaries (b). 
As can be seen in the presented examples (Fig. 3), the resulting crystalline grains do not contain defects. The resulting structure in them is clean and ideal, which indicates that defects are formed during crystallization at the last stage - at grain boundaries and triple junctions. It should be noted that the width of different grain boundaries is visually approximately the same. In [21], it was shown that it is approximately $5 \AA$, if measured by the diffusion permeability of the boundaries. Disclinations in triple junctions were not observed in this work.

Low- and high-angle boundaries in Fig. 3 are noticeably different. The former are characterized by a periodic distribution of free volume, while the latter - by a continuous one. Low-angle tilt boundaries, as is known, are periodically located edge dislocations $[17,19,22]$, while it is not possible to distinguish them at high-angle ones.

First of all, when conducting these studies, attention was paid to whether the free volume is blocked during crystallization at the triple junctions. As can be seen in Fig. 3, the free volume, in fact, is concentrated in the region of the junctions to a greater extent than at the grain boundaries. It should be borne in mind, however, that the free volume in the process of diffusion can partially go along the grain boundaries to the free surface, and also move to the boundaries when the junction migrates, as was shown in [14]. However, the results indicate that triple junctions are the preferred site for concentration of free volume.

Comparing with the results of our previous work [12], it should be said that in the present model, stretched subgrains were not observed in the final structure. They appeared in the process of crystallization, but in the end they "healed", being absorbed by growing grains. The result reported in [12] is apparently explained by the relatively low temperature of the thermostat, insufficient for the normal evolution of the polycrystalline structure.

\section{Conclusions}

The molecular dynamics simulation of nickel crystallization from several crystalline nuclei was carried out. The orientation of the crystal lattice in the nuclei was set randomly, but so that, as a result of crystallization, tilt boundaries with a misorientation axis $<100>$ or $<111>$ are obtained. It is shown that the free volume during crystallization is predominantly concentrated at grain boundaries and triple junctions, especially at the latter, i.e. where crystallization fronts are encountered and solidification occurs last. The increased content of free volume in triple junctions compared with grain boundaries is explained by the fact that when three crystallization fronts meet, the pockets of the liquid phase are formed, in which the density is lower than in the crystalline phase.

The grain growth rate during crystallization did not depend on the orientation of their crystal lattice. The velocity of crystallization front motion is several tens of times lower than the speed of sound in a metal, therefore, defects, as a rule, are formed at the final stage, when the fronts meet, i. e. at grain boundaries and triple junctions. Disclinations at triple junctions were not observed in this work. Subgrains with a different orientation from the neighboring grains and in a stretched state, the formation of which in the region of triple junctions was noted by us earlier in [12], were also observed in this study. But they were unstable and "healed" relatively quickly, being absorbed by neighboring growing grains.

\section{References}

1. A. I. Gusev. Physics-Uspekhi. 41, 49 (1998). Crossref

2. A. A. Nazarov, R. T. Murzaev. Letters on Materials. 8, 5 (2018). Crossref

3. A. A. Nazarov. Letters on Materials. 8, 372 (2018). Crossref

4. B. Bokstein, V. Ivanov, O. Oreshina, A. Peteline, S. Peteline. Materials Science and Engineering: A. 302, 151 (2001). Crossref

5. B.S. Bokstein, A. O. Rodin, B. B. Straumal. Defect and Diffusion Forum. 309-310, 231 (2011). Crossref

6. M. Wegner, J. Leuthold, M. Peterlechner, X. Song, S. V. Divinski, G. Wilde. Journal of Applied Physics. 116, 093514 (2014). $\underline{\text { Crossref }}$

7. D. L. Beke, A. Lakatos, G. Erdelyi, A. Makovecz, G. A. Langer, L. Daroczi, K. Vad, A. Csik. Defect and Diffusion Forum. 312 - 315, 1208 (2011). Crossref

8. A.A. Fedorov, M. Yu. Gutkin, I.A. Ovid'ko. Scripta Materialia. 47, 51 (2002). Crossref

9. P. Rodriguez, D. Sundararaman, R. Divakar, V.S. Raghunathan. Chemistry for Sustainable Development. 8, 69 (2000).

10. H.E. Schaefer, R. Wurschum, R. Birringer, H. Gleiter. Physical Review B. 38, 9545 (1988). Crossref

11. F. Muktepavela, G. Bakradze, V. Sursaeva. Journal of Materials Science. 43, 3848 (2008). Crossref

12. G.M. Poletaev, D. V. Novoselova, I. V. Zorya, M.D. Starostenkov. Physics of the Solid State. 60, 847 (2018). $\underline{\text { Crossref }}$

13. S.G. Psakhie, K.P. Zolnikov, D.S. Kryzhevich, A. V. Korchuganov. Scientific Reports. 9, 3867 (2019). Crossref

14. D. V. Novoselova, G. M. Poletaev, V. V. Kovalenko. Letters on Materials. 8, 11 (2018). (in Russian) [Д.В. Новоселова, Г.М. Полетаев, В.В. Коваленко. Письма о материалах. 8, 11 (2018).] Crossref

15. E. V. Kozlov, N.A. Koneva, N.A. Popova. Physical Mesomechanics. 12, 280 (2009). Crossref

16. F. Cleri, V. Rosato. Physical Review B. 48, 22 (1993). Crossref

17. G. Poletaev, I. Zorya, R. Rakitin. Computational Materials Science. 148, 184 (2018). Crossref

18. G. M. Poletaev, I. V. Zorya, R.Y. Rakitin, M.A. Iliina. Materials Physics and Mechanics. 42, 380 (2019).

19. G. M. Poletaev, I.V. Zorya, M.D. Starostenkov, R. Yu. Rakitin, P. Ya. Tabakov. Journal of Experimental and Theoretical Physics. 128, 88 (2019). Crossref

20. W.-L. Chan, R.S. Averback, D. G. Cahill, Y. Ashkenazy. Physical Review Letters. 102, 095701 (2009). Crossref

21. G. M. Poletaev, D. V. Dmitrienko, V.V. Diabdenkov, V.R. Mikrukov, M.D. Starostenkov. Physics of the Solid State. 55, 1920 (2013). $\underline{\text { Crossref }}$

22. A. I. Dmitriev, A. Yu. Nikonov. Facta Universitatis, Series: Mechanical Engineering. 15, 285 (2017). $\underline{\text { Crossref }}$ 